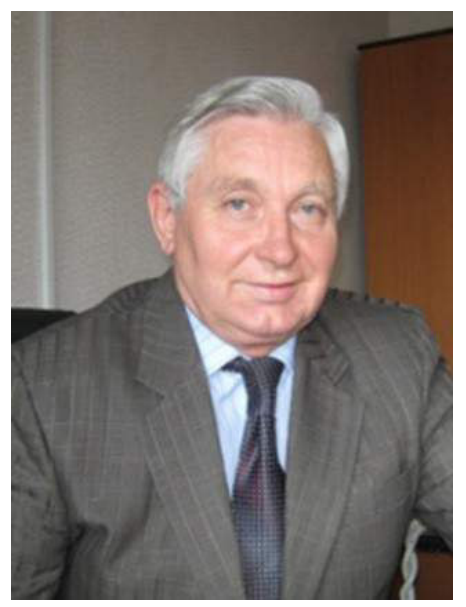

Іван Бех,

доктор психологічних наук, дійсний член НАПН України, директор Інституту проблем виховання НАПН України

(м. Київ, Україна)

\section{Ivan Bekh,}

Doctor of Psychological Sciences, Full Member of the National Academy of Pedagogical Sciences of Ukraine, Director of the Institute for Educational Problems of the National Academy of Pedagogical Sciences of Ukraine (Kyiv, Ukraine) ipv@ipv.org.ua

\title{
ЗРОСТАЮЧА ОСОБИСТІСТЬ ЯК СУБ'ЄКТ ДУХОВНИХ ЦІННОСТЕЙ
}

Анотація. У статті розкривається динаміка категорії «дух» у контексті проблем виховання зростаючої особистості. У цьому плані методика має справу з конструктами «духовність» і «Я-духовне». Наголошується, що кінцевою метою виховного процесу повинна бути духовно розвинена особистість. Кожен вихованець мусить стати суб'єктом власної духовної «Я-системи», використовуючи її в регуляції своєї поведінки, діяльності, спілкування.

Досягти цю кінцеву мету можливо в організованому Я-центрованому розвивальному вихованні, яке ґрунтується на етичній свідомості та етичній рефлексії.

Аналізуються дві суб'єкт-суб'єктні відносини, які необхідно рівною мірою утверджувати в процесі сходження підростаючої особистості до духовних цінностей. Пропонуються психологічні засоби підвищення стійкості духовної Я-системи.

Ключові слова: дух, духовність, етична свідомість, етична рефлексія, Я-система, Я-центроване розвивальне виховання.

\section{A GROWING-UP PERSONALITY AS A SUBJECT OF SPIRITUAL VALUES}

Abstract. The article is devoted to the dynamics of the category of «spirit» in the context of education of a growing-up personality. In this case, the methods have to deal with constructs «spirituality» and «Self-spiritual». It is noted that a spiritually developed person should be the ultimate goal of the educational process. Each student has to become a subject of his own spiritual "Self-system» using it in the regulation of his behaviour, activity and communication. To reach this ultimate goal is possible during an organized self-centered developmental education based on ethical consciousness and ethical reflection.

Two types of subject-subject relations that should be maintained equally when the growing-up personality ascents to spiritual values have been analyzed. The author offers psychological means of improving sustainability of student's spiritual Self-system.

Keywords: spirit, spirituality, ethical consciousness, ethical reflection, Self-system, self-centered developmental education.

\section{ВСтуп}

Постановка проблеми. Проблема духовності владно охоплює сферу опіки сучасного виховного процесу. Це вимагає перш за все відповідного теоретичного упорядкування.

Категорія «дух» має тривалу історію. Уявлення про нього усталено пов'язувалось із так званою людиною безпосередньою, прагнення якої обмежувались лише буттєвою сферою. У ракурсі життєвих речей людини дух виступав загальним механізмом надання цим речам відповідної значущості. Якраз у такому розумінні переважно говорять про зайнятість світу духовними проблемами.

Однак по мірі того, як змінювалось уявлення про справжній сенс життя людини, її вище призначення, категорія «дух» набуває цільової функції як привласнення нею високої духовності. I саме у цьому має полягати головний предмет піклування людини «здобувати дух». Відтак, вибудувалась провідна лінія дух - духовність - Я (духовне), що задала стратегію теоретичного і технологічного осмислення виховного процесу.

При цьому виходитимемо з того, що сучасні реалії життя $є$ такими, за яких справжня духовність, на жаль, падає у ціні. Тому потрібні широкозахоплювальні впливи, щоб вона могла набути належного престижу, і в результаті цього реальністю стала духовно розвинена особистість.

Відмінність духовності від інших (розумових, художніх) обдарувань полягає в тому, що коли останні об'єктивно притаманні не всім людям, особливо щодо геніальності, то духовними цінностями мусять володіти всі люди, хоча із різним ступенем прояву.

Найбільша методична вада сучасного виховного процесу полягає в тому, що зростаюча особистість у своєму становленні зупиняється лише на знанні духовності, не стаючи її повноцінним носієм і представником. 


\section{РЕЗУЛЬТАТИ ДОСЛІДЖЕННЯ}

У вихованні духовності слід виходити з того, що індивід народжується з налаштованістю до розвитку якраз Я-духовного, становлення самого себе як особистості. Було б добрим знаком, якби цей розвиток виявлявся однозначно продуктивним. Однак цього не трапляється: Я-духовне завжди зустрічає перепони як зовнішні, так і внутрішні, які впливають на його якість, гальмуючи чи зміщуючи його в негативний бік.

Вихованець мусить початково максимально усвідомити духовність (цінності, що її складають) як дію-вчинок, поведінку в цілому. І це діяльнісне відображення добра попереджатиме пасивність, яка йому притаманна і яка виникає в навчальному процесі, коли більшість знань об'єктивно не могли бути використані в реальній практиці. 3 іншого боку, на основі саме такого розуміння духовності мають створюватися відповідні технології виховання у зростаючої особистості.

Стосовно осягнення особистістю самої себе (своїх розумових, моральних, соціокультурних надбань) введена категорія «Я-концепція». Однак у плані розуміння особистістю власної внутрішньої духовної картини слід ввести більш логічно строгу «Я-система». У ній має фріксуватися ієрархія цінностей за їх смисловою висотою, узагальненістю і підпорядкованістю, а також місце нижчих душевних пристрастей і емоційних переживань, більш чи менш стійких почуттєвих утворень.

Кожний вихованець має стати суб'єктом власної «Я-системи», використовуючи її у регуляції своєї поведінки, діяльності, спілкування. Щоб вихованець піднявся до такої надздібності, він мусить усвідомити, що духовна самосвідомість, на основі якої формується «Я-система», не є актом самоспоглядання, а вона виступає складною дією, якою слід спеціально оволодіти і надати внутрішнього сенсу.

Із самосвідомістю пов'язується й вершинна мета розвитку особистості - набуття власної суб'єктності, під якою розумітимемо ії̈ здібність у кожній ситуації і за будь-яких обставин самостійно визначати свої соціальні дії і в кінцевому підсумку свою життєву спрямованість. Здібність, про яку йдеться, є широко узагальненим утворенням, а значить, проходить тривалий час становлення, коли конкретні ситуації змушують особистість внутрішньо їх упорядкувати за соціальними способами вирішення і відповідною мотивацією. I лише після цього можливе узагальнення власних дій як показників суб'єктності особистості. Слід наголосити якраз на мотиваційному узагальненні, оскільки від їх змісту безпосередньо залежатиме й життєва спрямованість особистості.

Інколи висловлюється судження - «це якраз та людина, яка потрібна», і це вважається ідеалом вихованості. Який же його глибинний сенс? Щоб правильно відповісти на це питання, слід спочатку з'ясувати авторів такого судження. Це здебільшого пересічні особи з переважаючими утилітарними цілями і прагненнями, 3 нерозвиненою духовністю. Вони й вважають за досконалу ту особистість, яка потрібна саме їм, яка була б суголосною їхнім життєвим поглядам і сприяла їх реалізації.

У дійсності духовно розвинена особистість повинна бути такою для себе і не боятися бути такою перед іншими, не відмовлятися заради них від своїх цінностей з усіма своїми особливостями. Те, що духовно примітивна группа може чинити доволі значний тиск на розвинену особистість - це є встановлено психологічною закономірністю. Відтак, така особистість повинна володіти ще й рішучістю, впевненістю в собі, щоб протистояти таким груповим зазіханням. Наголосимо, що через перший духовний вчинок у вихованця входить початкова духовність. Звідси розуміння ним істини - «Я духовна особистість» - як основний мотив його подальших духовнихдіянь.

Щодо цієї розвивальної істини, слід наголосити наступне. Золотим правилом набуття зростаючою особистістю духовності має стати усвідомлення нею себе як носія духовності. Це правило вже увійшло сааме в такому формулюванні - у виховний ужиток педагога. Воно реалізується ним як процесс розгортання у вихованця духовно-морального самоусвідомлення, ціннісно перетворювальна сила якого досить значна.

При використанні означеного правила все ж слід, по-перше, зважати на те, що вихованець може проявляти два види ставлення до духовності. За першого виду він повністю не усвідомлює духовність як таку. Суттю другого виду є те, що вихованець, не усвідомлюючи духовність, все ж спонтанно повернутий до неї. Свідченням цього є та обставина, що під час спілкування на цю тему він не демонструє повної байдужості чи якихось негативних переживань. Тож внутрішня розгорнутість до духовності - це вже важливий момент в оволодінні вихованцем духовністю.

По-друге, бажано, щоб вихованець усвідомлював себе як носія духовності, так би мовити, не віч-на-віч із нею як з абстрактним етичним утворенням, а долучаючи до такої зустрічі її творців і зберігачів (певних персоналій, народ, державу). У цьому плані слід спрямувати мислення вихованця на те, щоб у нього судження «я носій духовності» ототожнювалось із судженням «я усвідомлюю себе перед моєю нацією як носій духовності». За останнього судження вихованець уподібнюватиме себе до нації не на основі своїх конкретних надбань, а актуалізуючи індивідуальне життя, у якому ці надбання формувалися і нині в ньому існують. Усе це підвищить рівень готовності вихованця прямувати шляхом духовності.

Зростаюча особистість повинна прокладати внутрішній шлях прямування до духовності свого вищого Я. Якщо цього не відбувається, тоді власне Я вона неодмінно обмежуватиме конкретними здібностями, уміннями, меркантильними прагненнями, елементарними життєвими інтересами і цим задовольнятиметься. Це свідчення того, що така особистість повернута назовні, до того, що називають справжнім активним життям, не розуміючи його істинного сенсу.

Без необхідних планомірних виховних впливів ця особистість набуває стійкого смаку до такого способу життя, і зламати таку настанову стає надзвичайно важко. Річ у тім, що вона може постійно підкріплюватись 
таким же за спрямованістю оточенням. Воно вважає, що означена особистість набула житейської мудрості і живе за її принципами, вчасно надаючи належне своїй власній персоні.

Особистість, про яку ми ведемо мову, не може глибоко проникнути в основу своєї почуттєвої природи через недостатність етичної рефлексії, тому якраз оточення часто-густо й виступає вирішальним фактором у ії̈ особистісній спрямованості. Воно навіює їй, що прямування до вищої духовності - це лише непотрібна трата часу, яку слід осуджувати і заперечувати. Цим самим у душі особистості зароджується стан духовної суперечності, неспокій, байдужість до справжніх цінностей життя. Тоді вона обирає шлях подвійних життєвих стандартів: зовнішньо така особистість демонструє (на жаль, лише словесно) свою високу суспільно значущу орієнтацію, внутрішньо ж у неї ціннісна пустота і примітивність, яку їй доводиться приховувати. Все ж може настати час, коли внутрішні поштовхи приведуть цю особистість до висновку, що вона не просто жива істота, але також і носій духовності, тоді й відбудеться відмова від наявного існування і прокинеться бажання кардинально інших цінностей. Духовно розвивальний процес на рівні індивідуальності, щоб його протікання було продуктивним, мусить мати сприятливі внутрішні умови, перш за все емоційного благополуччя, відповідної піднесеності високопочуттєвих надбань вихованця. Але така внутрішня картина у дійсності видається нереальною. ІІї створенню часто-густо заважають певні знегоди глибокої негативної емоційної насиченості, які виникають у результаті різноманітних життєвих обставин.

$€$ лише один механізм реагування на них - терпіння, до якого, до речі, зростаюча особистість далеко не завжди готова. Однак за механізму терпіння забезпечується лише перший етап, призначення якого полягає в тимчасовому знятті стану знегоди. На другому - більш важливому - етапі має відбутися якісно відмінне перетворення цього стану в стан душевної стійкості. Лише він виступає необхідним внутрішнім підгрунтям виховання духовних цінностей.

Особливістю означеного стану $є$ те, що досягти його шляхом самонавіювання чи самонаказу неможливо. Часто особистість, що перебуває у стані знегоди, пасивно віддає себе часові. Усе ж піднятися до душевної стійкості і перебувати в ній зростаюча особистість зможе, якщо вона набуде досвіду розгляду певної знегоди у силовому полі власних реально діючих високосмислових цінностей. Тут вона спрямовано зосереджується на них, відтворюючи і саму себе в ситуації певного суспільно значущого діяння й оточення, у якому воно розгорталося, і ті суспільні оцінювання, які завершували його.

Якраз повторення такого внутрішнього способу й призведе до того, що духовна цінність виступить стабілізуючою силою позитивного душевного стану вихованця. Відтепер така цінність виявиться не лише інструментом утвердження суспільно значущої зовнішньої поведінки, а й засобом наведення психологічного ладу вихованця.

У Я-центрованому розвивальному вихованні слід ураховувати дві психосоціальні орієнтації особистості, які визначають тип її поведінки. Їх умовно можна кваліфікувати орієнтацією-слабкістю та орієнтацією-настійливістю. Особистість з орієнтацією-слабкістю виразно проявляє цю рису в ситуаціях душевного напруження - прийняття відповідальних рішень, смислоціннісного вибору, тобто в ситуаціях реального складного і неоднозначного життя як дії, поведінки, спілкування. Спочатку емоційно реагуючи розпачем, після цього вона вагається, часто вдається до очікування. У цьому випадку проблеми, які виникають перед нею, особистість пов'язує з часом, сподівається на нього: час усе розставить на свої місця, якось усе вирішиться.

У цілому їі ставлення до проблем характеризується пасивністю в тому сенсі, що такій особистості сама зовнішня ситуація диктує свою проблему в сукупності мети та умов, у яких вона задається (наприклад, як повестися щодо вимог ровесників: прийняти їх чи відмовитися).

Проблемні ситуації своїм змістом та мотиваційною спрямованістю чинять тиск на особистість з орієнтацієюслабкістю, обмежують таким чином її увагу, перешкоджаючи долучити до певної проблеми власний досвід, набуті здібності та вміння, комунікативні резерви. Тільки поширивши свою увагу за межі актуальної ситуації на власне Я, означена особистість може досягти успіху.

Особистість із орієнтацією-настійливістю активно шукає спосіб вирішення певних проблем. Кожну з них вона розглядає в контексті власних потенційних можливостей. Тому емоція хвилювання, яка первісно виникає на етапі зародження певної проблеми, не в змозі перешкодити розглядати її цілісно. Настійливість такої особистості, яку вона використовує, якраз про це свідчить. Адже ця риса відображає вищий рівень ії особистісного Я, пов'язаний із самосвівдомістю та волею. Саме з цих складових власного Я така особистість вичерпує необхідну психічну енергію для досягнення прийнятої мети, а не обмежується лише нижчим емоційним підгрунтям.

Я-центроване духовно розвивальне виховання, яке ми утверджуємо, передбачає центральну мету - забезпечити умови, за яких вища духовність була б внутрішньо притаманна Я особистості. Стратегічний принцип у досягненні цієї мети полягає в положенні, згідно з яким вирішальними є не зовнішньо підкріплювальні впливи, за яких вихованець перебуває у пасивній позиції, а ті, що виходять із самого Я, з його суспільно значущого рівня, який, у свою чергу. теж спрямовано формується. Якраз активність Я є вирішальною в духовному розвитку зростаючої особистості, і завданням вихователя в цьому плані має бути забезпечення її в процесі суб'єкт-суб'єктної взаємодії. Тож перше, що повинен здійснити вихованець під керівництвом вихователя, - це прийняти власну духовну зміну як своє безпосереднє завдання, яке він має успішно вирішити, використовуючи всі свої внутрішні емоційно-розумові та вольові резерви. При цьому правильно організувати ці резерви, щоб вони не були хаотичними, має допомогти спільно з вихователем вибудувана гіпотеза як система умов, за межі яких не повинні виходити дії вихованця, а залишатися в середині її. 
Тут має стати в нагоді й механізм долучення до себе значущих людей, перш за все свого роду, а потім і інших. Таке долучення є нічим іншим як запозиченням кращих цінностей значущих осіб роду вихованця. Він приймає в себе суспільно важливий внесок попередніх поколінь, і в той же час це ставить перед ним завдання самому здійснити свій внесок заради майбутніх поколінь. Можна сказати й по-іншому: вихованець мусить міцно триматися за рід силою особистісної рефлексії.

Тож у вихованця має сформуватися не тільки уявлення, а чітке переконання, забарвлене позитивними переживаннями, що якраз через вищі ціннісні смисли він вступає у відносини з вихователем. Вони мають бути домінуючими, оскільки поряд з ними реально функціонують і відносини нижчого буттєвого сенсу, за якими упорядковується життєдіяльність вихованця в певному віковому періоді. Ці відносини теж можуть бути доцільно керованими, особливо на перших етапах їх виникнення, оскільки згадане впорядкування має розгортатися лише в суспільно значущих межах. У цьому зв'язку є небезпека, що вихованець може виходити за ці межі через недостатню духовно-моральну стійкість.

Доцільно розрізняти два типи відносин, які мають рівною мірою проявлятися в процесі сходження підростаючої особистості до духовних цінностей. Перший тип кваліфікуватимемо відносинами обопільно перетворювальними, які виникають та існують між вихователем і вихованцем на етапі свідомого привласнення останнім певної духовної цінності. Вони ґрунтуються не на формальній поверхневій міжособистісній взаємодії, а на глибинній сутнісній основі вихователя й вихованця і в різній мірі змінюють один одного. Тут найвищі почуття поваги, любові, піклування $€$ визначальними у виховних міжособистісних взаєминах. Поряд з відносинами обопільно перетворювальними доцільно вичленити відносини односторонньо перетворювальні, які теж мають проявлятися між вихователем і вихованцем. Наголошення на тому, що вони повинні проявлятися, має принципове значення, оскільки таке явище не є закономірним і спонтанним. Розкриємо цю міжособистісну ситуацію. По-перше, односторонньо перетворювальні відносини можуть проявлятися лише на етапі, коли вихованець здійснює вчинок, мотивований тією чи іншою духовною цінністю. По-друге,- і це найважливіше, - коли в процесі цього здійснення він відтворює ті духовні характеристики, які демонстрував вихователь як внутрішні засоби у виховному процесі, спрямованому на духовне зростання вихованця. Якщо така внутрішня робота вихованця відсутня, місця означеним відносинам у його духовному діянні не буде, і це істотно збіднить його внутрішню духовну картину.

Надзвичайно важливою умовою в сходженні підростаючої особистості до вищих духовних цінностей $є$ забезпечення їх стійкості у духовній Я-системі вихованця, не дозволяти їм девальвуватися чи взагалі зникнути з його внутрішнього особистісного досвіду. На жаль, тут ще багато науково незвіданого.

Зупинимося лише на деяких фррагментах, які можуть пролити світло на означену умову. Відомо, що у Я особистості існують різні за ціннісною спрямованістю складові. Особливо небезпечними у цьому плані виявляються різноманітні Его-пристрасті та нижчі емоційні прагнення, що супроводжують щоденне буття особистості. За звичного перебігу внутрішнього життя, коли особистість не звертається до його протікання, не вичленяє окремих станів, згадані емоційні складові зливаються з високими смислоціннісними утвореннями і виступають як недиференційоване ціле. Тому самостійно осягнути певні залежності між ними особистості досить важко. Так створюється внутрішнє підґрунтя для особистісно деструктивних змін вихованця.

Тож його завдання полягатиме в тому, щоб, по-перше, розчленувати нижчі й вищі складові власного Я, подруге, ізолювати духовні утворення не просто від нижчих емоційних складових, а утвердити набуті духовні цінності як певний окремий внутрішній світ, який має бути визначальним у особистісній сутності вихованця. Якраз у такій іпостасі він має сприймати самого себе і вибудовувати взаємини з людським довкіллям.

Ця внутрішня самоперетворювальна робота видається конче необхідною для забезпечення духовної стабільності. Ї̈̈ підсилюватиме й звернення особистості до власного життя, але в тому його сегменті, який пов'язаний з відхиленням від змісту привласнених духовних цінностей, тобто з ситуаціями, які мотивувалися Его-спонуками вихованця. Він повинен чітко відтворити такі ситуації, пов'язати кожну 3 них 3 конкретним егоцентрованим мотивом, дати йому об'єктивну оцінку та стати у зв'язку з цим у самокритичну позицію. Таке цілісне розумове осягнення минулих подій має викликати й адекватний емоційний відгук; без цього воно не буде продуктивним. Йдеться про переживання відрази, а то й огиди до суспільно несхвальних життєвих ситуацій. Це нові переживання в душевній картині вихованця, оскільки мова йде про його особистісний набуток, який знаходив поведінкове втілення. Звично він їх відчував стосовно матеріальних речей і об'єктів, з якими спорадично вступав у певний контакт. Тож вони об'єктивно знаходились на периферії емоційного існування вихованця. Відтепер вони мусять зміститися в його духовно-ціннісну структуру, стати частиною його Я-духовного.

При цьому слід зрозуміти, що згадані емоційні переживання актуалізуються не самі по собі, а за допомогою певного внутрішнього поштовху. Таким $є$ набутий позитивний емоційний досвід діяння, який за законом контрасту породжує протилежний. Звичайно, що для такого внутрішнього явища потрібен і спрямований поштовх вихователя.

Саме за таких запропонованих дій $є$ сподівання, що зростаюча особистість не втрачатиме духовне набуте, а воно служитиме для неї єдиним дієвим орієнтиром у духовно досконалому житті.

У цій складній внутрішній діяльності має визріти особливий ціннісний феномен - духовне самопіклування, тобто піклування про своє Я-духовне, яке зростаюча особистість повсякчас захищатиме, використовуючи в першу чергу власну відповідальність. I тут знову-таки прослідковується шлях від піклування про зовнішнє до піклування про себе у вищому ціннісному вимірі. Останнє вдається особистості набагато важче, ніж попереднє, 
тому й потрібна відповідна системна підготовча душевна праця. Вона безпосередньо спрямовується на те, щоб не сконцентровуватися на егоїстичних насолодах і наслідках, що з них випливають. В іншому випадку у зростаючої особистості навіть не з'явиться думка, що слід віддавати честь людській величі, і не на словах, а достойним життям у всьому його розмаїтті. Усе ж не слід вважати, що таке високоціннісне життя ґрунтуватиметься весь час на духовній відповідальності. Якщо вміло культивувати стан натхнення, тоді воно виступить механізмом перетворення відповідальності як обов'язку у власне бажання особистості. Відтак, вона може стверджувати, що моє духовне бажання $є$ моїм духовним обов'язком. Це і $€$ вершина духовного саморозвитку людини.

\section{ВИСНОВКИ ТА ПЕРСПЕКТИВИ ПОДАЛЬШИХ ДОСЛІДЖЕНЬ}

Пам'ятатимемо, що справжня духовність - важка ноша, яку взяв на себе вихованець; вона не з тих внутрішніх утворень, як певні розумові чи фрізичні досягнення-здібності, які однаково позитивно сприймаються зовнішнім оточенням і таким же способом оцінюються та безпосередньо впливають на його соціальний статус. Тож носій духовності самим цим фактом виступає своєрідним подразником для тих, хто нею не володіє. Тому не виключена ситуація, коли такий вихованець може виявляти прагнення навіть приховати свою духовну перевагу, і це один із можливих способів забезпечити собі западину серед ціннісно неоднозначної реальності.

Слід лише розрізняти особистість із помилковою подібністю духовності. Така особистість проводить звичне життя: чогось бажає, чимось насолоджується, чогось очікує. Однак вона завжди перебуває в стані пасивності, навіть у своїх елементарних прагненнях: вони залишаються прямо не визначеними, як нібито дитина говорить «мені хочеться» (а не «я хочу»). Все життя такої особистості зводиться лише до емоційних переживань приємного і неприємного. У межах цих переживань у неї складається й уявлення про життєве щастя. Тож ӥй слід багато попрацювати, щоб змінити таку ціннісну позицію.

Розкриті нами глибинні психологічні чинники свідомого оволодіння зростаючою особистістю духовними цінностями дозволяють вичленити ряд пріоритетів сучасного виховання.

- Зміст духовно розвивального виховання має сповна акумулювати культуровідповідні форми життя сучасного суспільства. Ці фрорми повинні бути препаровані в контексті їх смислоціннісних детермінант як реальних мотивів поведінки, діяльності і спілкування суб'єктів виховного процесу.

- Духовно-моральну вихованість підростаючої особистості слід інтерпретувати як нарощування їі гуманістичного потенціалу.

- На індивідуальному рівні означений потенціал імплементується в особистісну свободу і соціальну відповідальність.

- Ц Ці характеристики виступають критеріями випереджального типу вихованця, який ми утверджуємо. Даний тип слід пов'язувати з процесом розвитку, що переходить у саморозвиток.

\section{СПИСОК ВИКОРИСТАНИХ ДЖЕРЕЛ}

[1] Бердяев Н. А. Дух и реальность . М. : АСТ, Харьков : Фолио, 2006. 679 с.

[2] Буева Л. П. Сакральность духовного пространства. Педагогика. 1995. № 5. С. 52-56.

[3] Вентцель К. Н. Свободное воспитание : сб. избр. трудов. М. : АПО, 1993. 364 с.

[4] Занков В. В. Духовность человека в зеркале психологического знания и религиозной веры. Вопросы психологии. 1998 . № 3. C. $104-114$.

[5] Зязюн І. А. Педагогіка добра: ідеали і реалії : наук.-метод. посіб. К. : МАУП, 2000. 308 с.

[6] Помиткін Е. О. Психологія духовного розвитку особистості : монографрія. К. : Наш час, 2007. 280 с.

[7] Савчин М. В. Духовний потенціал людини. Івано-Франківськ : Вид-во «Плай» Прикарпатського ун-ту, 2001. 203 с.

[8] Франкл С. Л. Духовные основы общества. М. : Республика, 1992. 511 с.

[9] Франкл С. Л. Человек в поисках смысла. М. : Прогресс, 1990. 368 с.

\section{REFERENCES (TRANSLATED AND TRANSLITERATED)}

[1] Berdjaev N. A. Dukh y realjnostj (Spirit and Reality). M. : AST, Kharjkov : Folyo, 2006. 679 s. (in Russian)

[2] Bueva L. P. Sakraljnostj dukhovnogho prostranstva (Sacral Spiritual Space). Pedaghoghika. 1995. № 5. S. 52-56. (in Russian)

[3. Ventcelj K. N. Svobodnoe vospytanye (Free education): sb. yzbr. trudov. M. : APO, 1993. 364 s. (in Russian)

[4] Zankov V. V. Dukhovnostj cheloveka v zerkale psykhologhycheskogho znanyja y relyghyoznoj very (A person's spirituality in the mirror of psychological knowledge and religious faith). Voprosy psykhologhyy. 1998. № 3. S. 104-114. (in Russian)

[5] Zjazjun I. A. Pedaghoghika dobra: idealy i realiji (Pedagogy of kindness: ideals and realities): nauk.-metod. posib. K. : MAUP, 2000. 308 s. (in Ukrainian)

[6] Pomytkin E. O. Psykhologhija dukhovnogho rozvytku osobystosti (Psychology of spiritual development of personality): monoghrafija. K.: Nash chas, 2007. 280 s. (in Ukrainian)

[7] Savchyn M. V. Dukhovnyj potencial ljudyny (Man's spiritual potential). Ivano-Frankivsjk : Vyd-vo «Plaj» Prykarpatsjkogho un-tu, 2001. 203 s. (in Ukrainian)

[8] Frankl S. L. Dukhovnye osnovy obshhestva (Spiritual foundations of society). M. : Respublyka, 1992. 511 s. (in Russian)

[9] Frankl S. L. Chelovek v poyskakh smysla (Man's search for meaning). M. : Proghress, 1990. $368 \mathrm{~s}$. (in Russian) 